\title{
NTECEDENTS AND OUTCOMES OF SERVICE RECOVERY SATISFACTION IN TELECOMMUNICATIONS IN CROATIA ALONG WITH THE ROLE OF IMAGE AND PERCEIVED SWITCHING COSTS
}

\author{
Ariana Nefat ${ }^{\mathrm{a}}$ \\ By Dragan Benazićb \\ Dražen Alerićc
}

The paper studies the effect of service recovery on the customer's satisfaction as well as the outcomes of service recovery satisfaction, along with the moderating role of the image and perceived switching costs as exemplified by mobile telecommunications in Croatia. Using the concept of justice, the research shows that distributive, procedural and interaction justice lead to service recovery satisfaction, which consequently

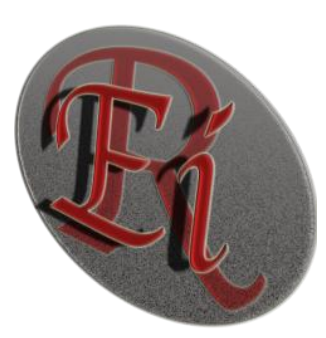

affects overall satisfaction and communication by word of mouth; these then strongly influence the customer's intention to return as a customer. The role of service recovery satisfaction seen as a variable of mediator has been confirmed, but not the image and switching costs as moderators. The role of service recovery satisfaction seen as a variable of mediator has been confirmed, but not the image and switching costs as moderators.

EEL:

M30

M31

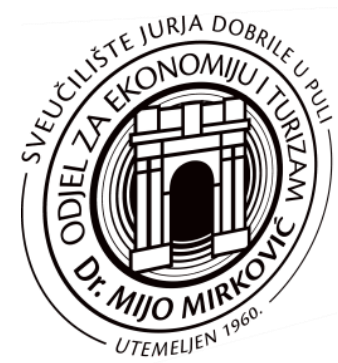

${ }^{a}$ Associate Professor, Ph.D., Juraj Dobrila University of Pula, Department of Economics and Tourism - Dr. Mijo Mirković, Pula, Preradoviceva 1/1,e-mail:astok@efpu.hr

${ }^{b}$ Ph.D.Juraj Dobrila University of Pula, Department of Economics and Tourism - Dr. Mijo Mirković, Pula, Preradoviceva 1/1, email:dbenazic@efpu.hr

'Ph.D.Juraj Dobrila University of Pula, Department of Economics and Tourism - Dr. Mijo Mirković, Pula, Preradoviceva 1/1, e-mail: drazen.aleric@unipu.hr 


\section{INTRODUCTION}

For recording desired business performance, providing immediately an service without failure is ideal. However, it is not always possible because of its features, consequently giving the importance to service recovery that is primarily given by the customers who have complaints about it. ${ }^{4}$ The aim of service recovery is to make the customer satisfied again since his/her satisfaction has severely been affected at providing the service for the first time, and thus to restore his/her lost confidence.5Dealing with the service-related problem and making the customer satisfied again, service recovery opens up the possibility of establishing a relationship with the customer and his/her loyalty to the benefits of both parties.

Despite the importance of service recovery, this area has recently drawn the attention of researchers. ${ }^{6}$ The aim of the paper is to investigate the effect of service recovery on the customer's satisfaction and his/her behavioral intentions through using mobile telecommunications in Croatia as an example. The explanation considering what affects the customer's satisfaction in the case of service recovery is given through the concept of justice, which is the most frequently studied model in the stated area. Depending on the satisfaction resulted from service recovery, what is developed refers to the perception of overall satisfaction with the company and the intention either to return as a customer or to leave the company, as well as positive or negative communication by word of mouth.'The corporate image and its characteristics have been used as the variable moderators ${ }^{8}$ (Urbonavičius, Ivanauskas, 2005, Nikbin, Ismail, Marimuthu, Jalalkamali, 2010), also the exit barriers, seen as a factor of behavioral intention after the service recovery, which are assumed to have a impact on the satisfaction with service recovery and the consequent behavior of customers in the mobile communication sector.

A list of the keywords should contain up to 8 words.

\section{SURVEY OF LITERATURE AND HYPOTHESES}

\section{A. Service Recovery}

Failures regarding services are difficult to avoid but companies may learn to respond to them efficiently. Service recovery refers to "the action taken by the service organization in response to a customer's expression of dissatisfaction with some aspect of the service".. Taking into account the fact that drawing the attention of new users costs five times more than retaining the existent ones, every procedure of service recovery can be justified. It starts when the service providing company which has not met the customer's expectations perceives and recognizes the failure. ${ }^{10}$ Realizing that the failure has been made, the customer becomes aware of a certain loss, so the

\footnotetext{
${ }^{4}$ Nidhi Sabharwal, Nidhi, Harmeen Soch, and Harsandaldeep Kaur, „Are we satisfied with incompetent services? A scale development approach for service recovery", Journal of Services Research, 10, no. 1 (2010): 125-142.

${ }^{5}$ Sparks, Beverly A., and Janet R. McColl-Kennedy, "Justice strategy options for increased customer satisfaction in a services recovery setting", Journal of Business Research, 54, no. 3 (2001): 209-218.

${ }^{6}$ Seungong Weun, Sharon E. Beatty, and Michael A. Jones, "The impact of service failure severity on service recovery evaluations and postrecovery relationships", Journal of Services Marketing, 18, no. 2 (2004): 133-146.

"Chiara Orsingher, Sara Valentini, and Matteo deAngelis, „A meta-analysis of satisfaction with complaint handling in services". Journal of the Academy of Marketing Science, 38, no. 2 (2010) 169-186.

${ }^{8}$ Sigitas Urbonavičius, and Robertas Ivanauskas, "Evaluation of Multiple Retailers' Market Positons on the Basis on Image Attributes Measurement", Journal of Business Economics and Management, 6, no.4, (2005): 199-206., Davoud Nikbin, Ishak Ismail, Malliga Marimuthu and Mohammad Jalalkamali, "Perceived Justice in Service Recovery and Recovery Satisfaction: The Moderating Role of Corporate Image", International Journal of Marketing Studies, 2, no. 2 (2010) 47-56.

${ }^{9}$ Beverly A. Sparks, and Liz Fredline, „Providing an Explanation for Service Failure: Context, Content, and Customer Responses, lournal of Hospitality \& Tourism Research, 31, no. 2 (2007): 241-260.

${ }^{10} \mathrm{lbid}$.
} 
task of the company is to make up for it. ${ }^{11}$ It is possible to regain the customer's satisfaction and loyalty through meeting his/her expectations in terms of service recovery, which includes understanding and respect, also fair treatment as a multidimensional concept comprising distributive, procedural and interaction justice. ${ }^{12}$

\section{B. Antecedents of Recovery Satisfaction}

\section{DISTRIBUTIVE JUSTICE}

Distributive justice is described as"fairness of the complaint outcome as the customer perceives it"..$^{13}$ The result may refer to "the actual money compensation, an apology, future free services, reduced charges, repairs, and/or replacements. ${ }^{14}$ It may be considered as something that is deserved, that meets the needs or that is fair. ${ }^{15}$ Among all these elements of justice, according to the meta-analysis by Orsingher, Valentini and de Angelis ${ }^{16}$, distributive justice is most strongly related to the satisfaction upon complaints (61\% of the researches), followed by interactionjustice (30\% of the researches)and, to the smallest extent, procedural justice in just $9 \%$ of the researches.

$\mathrm{H1}$ : Distributive justice is positively related to recovery satisfaction

\section{PROCEDURAL JUSTICE}

Procedural justice refers to the expected"fairness in terms of policies, rules, and timeliness of the complaint process". ${ }^{17}$ The perception of procedural justice is affected by the possibility of customers to express their feelings and to follow certain procedures regarding service recovery.$^{18} \mathrm{Among}$ the dimensions of procedural justice, the speed at which a complaint is being processed, especially when the customer is upset, can be emphasized. ${ }^{19} \mathrm{~S} / \mathrm{he}$ can be particularly affected when it is believed that $\mathrm{s} / \mathrm{he}$ is not right or lies, so $\mathrm{s} /$ he finds herself/himself in a situation to prove her/his rights. ${ }^{20}$

$\mathrm{H}$ 2: Procedural justice is positively related to recovery satisfaction

\section{INTERACTION JUSTICE}

Interaction justice refers to "the perceived fairness of the behavior that employees exhibit toward complainants". ${ }^{21}$ t may be seen as a sub-element of procedural justice since it enables employees to conduct the organizational processes of service recovery through their behavior. ${ }^{22}$ Schoefer $^{23}$

\footnotetext{
${ }^{11}$ Patterson, Paul G., Elizabeth Cowley, and Kriengsin Prasongsukarn. "Service failure recovery: The moderating impact of individual-level cultural value orientation on perceptions of justice", International Journal of Research in Marketing, 23, no. 3 (2006) 263-277.

${ }^{12}$ Davoud Nikbin, Ishak Ismail, Malliga Marimuthu, and Mohammad Jalalkamali, „Perceived Justice in Service Recovery and Recovery Satisfaction: The Moderating Role of Corporate Image", International Journal of Marketing Studies, 2, no. 2 (2010) $47-56$.

${ }^{13}$ Christian Homburg, and Andreas Furst, "How Organizational Complaint Handling Drives Customer Loyalty: An Analysis of the Mechanistic and the Organic Approach", Journal of Marketing, 69, no. 3 (2005): 98.

${ }^{14}$ Valerie A. Zeithaml, Mary J. Bitner and Dwayne D. Gremler, Services Marketing (New York: McGraw-Hill, Irwin, 2006).

${ }^{15}$ Stephen S. Tax, Stephen W. Brown, and Murali Chandrashekaran, "Customer Evaluations of Service Complaint Experiences: Implications for Relationship Marketing", Journal of Marketing, 62, no. 2 (1998): 60-76.

${ }^{16}$ Chiara Orsingher, Sara Valentini, and Matteo deAngelis, „A meta-analysis of satisfaction with complaint handling in services". Journal of the Academy of Marketing Science, 38, no. 2 (2010) 169-186.

${ }^{17}$ Valerie A. Zeithaml, Mary J. Bitner and Dwayne D. Gremler, Services Marketing (New York: McGraw-Hill, Irwin, 2006).

${ }^{18}$ Sparks, Beverly A., and janet R. McColl-Kennedy, "Justice strategy options for increased customer satisfaction in a services recovery setting", lournal of Business Research, 54, no. 3 (2001): 209-218.

${ }^{19}$ leffrey G. Blodgett, Donna J. Hill, and Stephan S. Tax. "The Effects of Distributive, Procedural, and Interactional Justice on Post-Complaining Behavior", Journal of Retailing, 73, no. 2 (1997): 185-210.

${ }^{20}$ Valerie A. Zeithaml, Mary J. Bitner and Dwayne D. Gremler, Services Marketing (New York: McGraw-Hill, Irwin, 2006).

${ }^{21}$ Christian Homburg, and Andreas Furst, "How Organizational Complaint Handling Drives Customer Loyalty: An Analysis of the Mechanistic and the Organic Approach", Journal of Marketing, 69, no. 3 (2005): 98.

${ }^{22}$ Michael A. McCollough, Leonard L. Berry, and Manjit S. Yadav, „An Empirical Investigation of Customer Satisfaction after Service Failure and Recovery", Journal of Service Research, 3, No. 2 (2000): 121-137.
} 
(2008) has proved that interaction fairness has the strongest direct influence on service recovery satisfaction.The behavior of employees should be fair and kind, while an apology is seen as a valuable element of interaction justice. ${ }^{24}$ The research conducted by Varela-Neira, VazquezCasielles and Iglesias ${ }^{25}$ has shown that apology increases user's service recovery satisfaction.

$\mathrm{H} 3$ : Interaction justice is positively related to recovery satisfaction

\section{Consequences of Satisfaction Recovery}

According to meta-analysis literature on the satisfaction with complaint handling, Orsingher, Valentini and deAngelis ${ }^{26}$ mention three relevant consequences of recovery satisfaction, such as: intent to return as a customer, communication by word of mouth, and overall satisfaction.

\section{INTENTION TO USE THE SERVICE AGAIN}

The efficient use of service may result in the bihevioral intention in the form of return intent, so Orsingher, Valentini and deAngelis ${ }^{27}$ find a consistent relationship betweenthe customer's satisfaction with complaint handling and his/her intention to use the service again. Recovering the service and retaining the customer are also justified in terms of profit since "companies can boost profits by almost $100 \%$ by retaining just $5 \%$ more of their customers" ${ }^{28}$

$\mathrm{H} 4$ : Recovery satisfaction is positively related to intention to return as a customer

\section{COMMUNICATION BY WORD OF MOUTH}

The aim of communication by word of mouth is defined as "the likelihood that one would favorably recommend a firm's product or service after a failure and recovery effort" ${ }^{29}$ According to the analysis by Orsinger, Valentini and deAngelis ${ }^{30}$, there is a fairly consistent positive relationship between satisfaction with complaint handling and communication by word of mouth; they also consider that it positively affects the customer's return intention.

$\mathrm{H} 5$ : Recovery satisfaction is positively related to positive communication by word of mouth

H6: Communication by word of mouth is positively related to customer's return intention

\section{OVERALL SATISFACTION}

Satisfaction can be seen at different levels. From the viewpoint of individual customer, it can be transaction-specific satisfaction related to one service experience and cumulative satisfaction perceived as an accumulated experience with a service during some time. Oliver ${ }^{31}$,Orsinger,

\footnotetext{
${ }^{23}$ Klaus Schoefer, "The role of cognition and affect in the formation of customer satisfaction judgements concerning service recovery encounters", Journal of Consumer Behaviour, 7, no. 3 (2008): 210-221.

${ }^{24}$ Amy K. Smith, Ruth N. Bolton, and Janet Wagner. "A Model of Customer Satisfaction with Service Encounters Involving Failure and Recovery", Journal of Marketing Research, 36, no. 3 (1999): 356-372.

${ }^{25}$ Concepcion Varela-Neira, Rodolfo Vazquez-Casielles, and Victor Iglesias, "The effects of customer age and recovery strategies in a service failure setting", Journal of Financial Services Marketing, 15, no. 1(2010): 32-48.

${ }^{26}$ Chiara Orsingher, Sara Valentini, and Matteo deAngelis, „A meta-analysis of satisfaction with complaint handling in services". Journal of the Academy of Marketing Science, 38, no. 2 (2010) 169-186.

${ }^{27}$ Ibid.

${ }^{28}$ Frederik F. Reichheld, and Earl W. Sasser Jr, „Zero Defections: Quality Comes to Services", Harvard Business Review, 68, no. 5 (1990): 105-111.

${ }^{29}$ James G. Maxham, and Richard G. Netemeyer, "Modeling customer perceptions of complaint handling over time: the effects of perceived justice on satisfaction and intent", Journal of Retailing, 78, no. 4 (2002): 239-252.

${ }^{30}$ Chiara Orsingher, Sara Valentini, and Matteo deAngelis, "A meta-analysis of satisfaction with complaint handling in services". Journal of the Academy of Marketing Science, 38, no. 2 (2010) 169-186.

${ }^{31}$ Richard L. Oliver, Satisfaction: A Behavioral Perspective on the Consumer, (The mcGraw-Hill Companies, Inc., 1997).
} 
Valentivi and deAngelis ${ }^{32}$ have stated that transaction-specific satisfaction with complaint handling is positively related to cumulative overall satisfaction. It is assumed that overall satisfaction will affect the customer's return intention and communication by word of mouth, as well. ${ }^{33}$

$\mathrm{H7}$ : Recovery satisfaction is positively related to overall satisfaction

$\mathrm{H} 8$ : Overall satisfaction is positively related to customer's return intention

H9: Overall satisfaction is positively related to positive communication by word of mouth

\section{Mediation Role of Recovery Satisfaction}

While the majority of studies start from the assumption that the effect of justice elements on purchase intention, communication by word of mouth and overall satisfaction is indirect through service recovery satisfaction, only a small number of studies does take into account the mediation effect of service recovery satisfaction. ${ }^{34}$

H10: Dimension of justice has a positive effect on communication by word of mouth and repurchase intention through the mediation of service recovery satisfaction.

\section{E. Moderating Role of Corporate Image and Switching Costs}

\section{CORPORATE IMAGE}

The image refers to 'how customers perceive an organization based on experience or impressions and how these perceptions create a set of associations that contribute to a total picture of the organization' ${ }^{35}$ The corporate image is considered to have a halo effect on the customer's satisfaction, with the service-related satisfaction affecting the company-related satisfaction ${ }^{36}$, and the service-related error does not necessarily damage the corporate image. ${ }^{37}$ Starting from the research conducted by Lai, Griffin and Babin ${ }^{38}$,the corporate image is an important predictor of user's satisfaction, following all justice dimensions.

$\mathrm{H} 11$ : The effect of distributive justice on recovery satisfaction is stronger when customers have the positive corporate image

$\mathrm{H} 12$ : The effect of procedural justice on recovery satisfaction is stronger when customers have the positive corporate image

H13: The effect of interaction justice on recovery satisfaction is stronger when customers have the positive corporate image

\footnotetext{
${ }^{32}$ Chiara Orsingher, Sara Valentini, and Matteo deAngelis, "A meta-analysis of satisfaction with complaint handling in services". Journal of the Academy of Marketing Science, 38, no. 2 (2010) 169-186.

${ }^{33}$ Richard L. Oliver, Satisfaction: A Behavioral Perspective on the Consumer, (The mcGraw-Hill Companies, Inc., 1997)., Christopher Lovelock and Jochen Wirtz. Services Marketing: People, Technology, Strategy, (Pearson Prentice Hall, 2007).

${ }^{34}$ James G. Maxham, and Richard G. Netemeyer, "Modeling customer perceptions of complaint handling over time: the effects of perceived justice on satisfaction and intent", Journal of Retailing, 78, no. 4 (2002): 239-252., Hui Liao, "Do It Right This Time: The Role of Employee Service Recovery Performance in Customer-Perceived Justice and Customer Loyalty After Service Failures", Journal of Applied Psychology, 92, no. 2 (2007): 475-489.

${ }^{35}$ Tor W. Andreassen, „From Disgust to Delight: Do Customers Hold a Grudge?", Journal of Service Research, 4, no. 1 (2001): $39-49$.

${ }^{36}$ Tor W. Andreassen, and Bodil Linedstad, "Customer Loyalty and Complex Services", International Journal of Service Industry Management, 8, no. 4: 1-33., Fujun Lai, Mitch Griffin, and Barry J. Babin, "How quality, value, image, and satisfaction create loyalty at a Chinese telecom" Journal of Business Research, 62, no. 10 (2009): 980-986.

${ }^{37}$ Davoud Nikbin, Ishak Ismail, Malliga Marimuthu, and Mohammad Jalalkamali, "Perceived Justice in Service Recovery and Recovery Satisfaction: The Moderating Role of Corporate Image", International Journal of Marketing Studies, 2, no. 2 (2010) 47-56.

${ }^{38}$ Fujun Lai, Mitch Griffin, and Barry J. Babin, "How quality, value, image, and satisfaction create loyalty at a Chinese telecom", Journal of Business Research, 62, no. 10 (2009): 980-986.
} 


\section{SWITCHING COSTS}

"Perceived switching costs are consumer perceptions of the time, money and effort associated with changing service providers". ${ }^{39}$ Switching costs in the area of mobile communication as a network industry ${ }^{40}$ may be considered relatively high.As perceived switching costs significantly influences user's loyalty ${ }^{41}$, it can be considered that switching costs decreases an influence of satisfaction on repurchase intention ${ }^{42}$. In the case of high switching costs dissatisfied customers, who probably spread negative information ${ }^{43}$, do not leave because of their perception that switching costs are higher than switching benefits. ${ }^{44}$

$\mathrm{H} 14$ : The effect of recovery satisfaction on purchase intention is weaker when switching costs are high

H15: The effect of service recovery dissatisfaction on negative communication by word of mouth is stronger when switching costs are high

\section{RESEARCH INTO RECOVERING SERVICES IN THE TELECOMMUNICATION SECTOR}

\section{A. Methodology}

\section{SAMPLE}

The research has been based on the structured questionnaire, administered to the population of students possessing mobile phones. 156 questionnaires were collected, 116 of them being useful. As for the remaining 40 questionnaires that were not taken into consideration, the students stated in 32 questionnaires that they had not had any problems while using mobile communication services; 8 questionnaires were neither correctly nor completely filled in. The answer regarding the type of failure at providing the service was elicited with the help of an openended question. Among the total number of failures, $56.8 \%$ of them referred to the problems caused by the quality of core product, $20.7 \%$ to the problems related to service costs and payments, $10.3 \%$ to the problems considering the product that follows the services, $6.1 \%$ to the problems with additional services, and $6.1 \%$ to the problems with providing services to customers. $39.7 \%$ of students made a contract with the service provider, while $60.3 \%$ of them did not have such a contract. The sample included $25 \%$ male subjects and $75 \%$ female subjects. The sample structure was based on study years considering the included students and time when the research was conducted. In terms of gender, it largely corresponded with the structure of the students enrolled at the Faculty of Economics throughout Croatia (66\% female and $44 \%$ male students), but also with the structure of all Croatian students with prevailing female ones ${ }^{45}$ (DZS,

\footnotetext{
${ }^{39}$ Michael A. Jones, David L. Mothersbaugh, and Sharon E. Beatty. "Switching Barriers and Repurchase Intentions in Services", Journal of Retailing, 76, no. 2 (2000): 262.

${ }^{40}$ Motta, Massimo. Competiton Policy: Theory and Practice, (Cambridge University Press, 2004).

${ }^{41}$ Wang, Yi-Shun, Shung-Cheng Wu, Hsin-Hui Lin, and Yu-Yin Wang. "The relationship of service failure severity, service recovery justice and perceived switching costs with customer loyalty in the context of e-tailing", International journal of Information Management, 31, no. 4 (2011): 350-359.

${ }^{42}$ Michael A. Jones, David L. Mothersbaugh, and Sharon E. Beatty, "Switching Barriers and Repurchase Intentions in Services", Journal of Retailing, 76, no. 2 (2000): 259-274.

${ }^{43}$ Christopher Lovelock, and Jochen Wirtz. Services Marketing: People, Technology, Strategy, (Pearson Prentice Hall, 2007).

${ }^{44}$ Michael Porter, Competitive Strategy: Techniques for analiysing industries and competitors, (New York: The Free Press, 1980).

${ }^{45}$ Croatian Bureau of Statistics (2012), Studenti u ak. godini 2010./2011.,http://www.dzs.hr/Hrv_Eng/publication/2012/S1-1445.pdf (retrieved on 10/09/2012)
} 
2012). Due to the above mentioned, it is possible to generalize the results regarding the student population.

\section{MEASUREMENTS}

The questionnaire (see Appendix) included 9 groups of statements. Distributive justice was covered by 4 statements, modified according to Tax, Brown, Chandrashekaran ${ }^{46}$, Blodgett, Hill, $\mathrm{Tax}^{47}$ and Smith, Bolton, Wagner. ${ }^{48}$ Procedural justice included 4 statements, formulated upon Maxham, Netemeyer ${ }^{49}$, Tax, Brown, Chandrashekaran ${ }^{50}$ and Smith, Bolton, Wagner..$^{51}$ Interaction justice was measured through 5 statements, adapted according to Maxham, Netemeyer ${ }^{52}$, Tax, Brown, Chandrashekaran ${ }^{53}$, Blodgett, Hill, Tax ${ }^{54}$ and Smith, Bolton, Wagner ${ }^{55}$. Satisfaction with the service recovery, overall satisfaction with the company and communication by word of mouth were measured with the help of 3 items, according to Maxham \& Netemeyer ${ }^{56}$. Purchase intention was measured by using the three-item scale, based on Maxham, Netemeyer ${ }^{57}$, The three corporate image statements were adapted from Lai, Chiu, Yang, Pai ${ }^{58}$, while the perceived switching costs were measured by using 4 items, based on Wang, Y-S., Wu, S.-C., Lin, H.-H., Wang Y.-Y.59.

In the case of any statement, the seven-degree Lykert type scale was used, from 1- I do not agree at all up to 7 - I completely agree; the only exception referred to the third item of overall satisfaction with the company when the subjects expressed their dis/satisfaction through using seven degrees from 1- very dissatisfied to 7-very satisfied, as well as to the items regarding purchase intention and communication by word of mouth where the intention was measured from 1-slightly probable to 7-very probable.

\footnotetext{
${ }^{46}$ Stephen S. Tax, Stephen W. Brown, and Murali Chandrashekaran, "Customer Evaluations of Service Complaint Experiences: Implications for Relationship Marketing", Journal of Marketing, 62, no. 2 (1998): 60-76.

${ }^{47}$ leffrey G. Blodgett, Donna J. Hill, and Stephan S. Tax, "The Effects of Distributive, Procedural, and Interactional Justice on Post-Complaining Behavior", Journal of Retailing, 73, no. 2 (1997): 185-210.

${ }^{48}$ Amy K. Smith, Ruth N. Bolton, and Janet Wagner, "A Model of Customer Satisfaction with Service Encounters Involving Failure and Recovery", Journal of Marketing Research, 36, no. 3 (1999): 356-372.

${ }_{49}^{49}$ ames G. Maxham, and Richard G. Netemeyer, „Firm Reap What They Sow: The Effects of Shared Values and Perceived Organizational Justice on Customers' Evaluations on Complain Handling", Journal of Marketing, Journal of Marketing, 67, no. 1 (2003): 46-62.

${ }^{50}$ Stephen S. Tax, Stephen W. Brown, and Murali Chandrashekaran, "Customer Evaluations of Service Complaint Experiences: Implications for Relationship Marketing", Journal of Marketing, 62, no. 2 (1998): 60-76.

${ }^{51}$ Amy K. Smith, Ruth N. Bolton, and Janet Wagner, "A Model of Customer Satisfaction with Service Encounters Involving Failure and Recovery", lournal of Marketing Research, 36, no. 3 (1999): 356-372.

${ }^{52}$ James G. Maxham, and Richard G. Netemeyer, „Firm Reap What They Sow: The Effects of Shared Values and Perceived Organizational Justice on Customers' Evaluations on Complain Handling", Journal of Marketing, Journal of Marketing, 67, no. 1 (2003): 46-62.

${ }^{53}$ Stephen S. Tax, Stephen W. Brown, and Murali Chandrashekaran, "Customer Evaluations of Service Complaint Experiences: Implications for Relationship Marketing", Journal of Marketing, 62, no. 2 (1998): 60-76.

${ }^{54}$ leffrey G. Blodgett, Donna J. Hill, and Stephan S. Tax, "The Effects of Distributive, Procedural, and Interactional Justice on Post-Complaining Behavior", Journal of Retailing, 73, no. 2 (1997): 185-210.

${ }^{55}$ Amy K. Smith, Ruth N. Bolton, and Janet Wagner, "A Model of Customer Satisfaction with Service Encounters Involving Failure and Recovery", Journal of Marketing Research, 36, no. 3 (1999): 356-372

56 /ames G. Maxham, and Richard G. Netemeyer, "Firm Reap What They Sow: The Effects of Shared Values and Perceived Organizational Justice on Customers' Evaluations on Complain Handling", Journal of Marketing, Journal of Marketing, 67, no. 1 (2003): 46-62.

${ }^{57}$ lames G. Maxham, and Richard G. Netemeyer, "Modeling customer perceptions of complaint handling over time: the effects of perceived justice on satisfaction and intent", Journal of Retailing, 78, no. 4 (2002): 239-252.,

${ }^{58}$ Chi-Shiun Lai, Chin-Jen Chiu, Chin-Fang Yang, and Da-Chang Pai, "The Effect of Corporate Social Responsibility on Firm Performance: The Mediating Effect of Industrial Brand Equity and Corporate Reputation", Journal of Business Ethics, 95, no. 3 (2010): $457-469$.

${ }^{59}$ Wang, Yi-Shun, Shung-Cheng Wu, Hsin-Hui Lin, and Yu-Yin Wang. "The relationship of service failure severity, service recovery justice and perceived switching costs with customer loyalty in the context of e-tailing", International Journal of Information Management, 31, no. 4 (2011): 350-359.
} 


\section{B. Results}

The collected data were analyzed by applying the PLS (Partial Least Square) methods. The PLS method enables a simultaneous analysis of interrelatedness between theoretical constructs, does not require variables-indicators to be normally distributed in a range of variances, enables the analysis of structural equations on smaller samples regardless the level of multi-colinear nature between independent variables. ${ }^{60}$ The SmartPLS 2.0 software was used for analyzing the collected data. These were analyzed in two stages. First, the measurement model was analyzed for checking the psycho-metric features of the applied measurement scales. For testing the hypotheses, the structural model was then determined. The interaction effects were tested according to the approach by Chin, Marcholin \& Newstad ${ }^{61}$ and Hensler, Fassot ${ }^{62}$. Apart from the independent latent variables and the variables of moderators, a construct was also included in the analysis, the one whose indicators resulted from multiplying all the variables of the indicator considering the latent independent variable and the indicator of moderators. In order to more easily interpret the obtained results before the construction and application of constructs which represented the interaction terms, all the variables had been centered in relation to means. ${ }^{63}$

\section{MEASUREMENT MODEL}

Through using the measurement model, one-dimensionality, reliability, convergent and discrimination validity of the applied measurement scales were tested. Before checking the measurement model, the measurement scales were cleaned to rationalize the number of indicator variables. So, the exploratory factor analysis was used for each construct and for all of them, as well as the calculation of Cronbach alpha coefficient after eliminating certain variables. The variables that were eliminated include those whose indicators have factor loadings under 0.7 on the corresponding factor (the corresponding factor explains less than $50 \%$ of the variance of indicator variable) or had significant factor loadings on more than one factor. In addition, the elimination included those variables whose elimination enabled an increase in Cronbach alpha coefficient above 0.8. Based on the exploratory factor analysis and Cronbach alpha coefficient, 5 indicator variables were eliminated, such as: PJUST2, IJUST5, RSAT2, OSAT2 and OBST4. After eliminating the above-mentioned variables, the measurement model was analyzed. The results of the measurement model checking and the selected indicators of psychometric characteristics are presented in Table 1.

\footnotetext{
${ }^{60}$ Joseph F. Hair and others, Multivariate Data Analysis, Upper Saddle River, (New Jersey: Pearson Education, 2009).

${ }^{61}$ Wynne W. Chin, Barbara L. Marcolin and Peter R. Newsted. "A Partial Least Squares latent variable modeling approach for measuring interaction effects: results from a Monte Carlo simulation studyand voice mail emotion/adoption study", in Proceedings of the Seventeenth international conference on information systems ed. Janice DeGross, Sirkka Jarvenpaa, and Ananth Srinivasan, (Cleveland, Ohio, 1996), 20-41.

${ }^{62}$ Joerg Hensler and Georg Fassot. "Testing Moderating effects in PLS Path Models: An Illustration of Available Procedures", in Handbook of Partial Least Squares: Concepts, Methods and Applications ed. Esposito Vinzi and others, (New York: Springer, 2010), 713-735.
}

${ }^{63}$ Leona S. Aiken and Stephen G. West. Multiple regression: Testing and interpreting interactions, (Newbury Park: Sage Publications, 1991), Charles M. Judd and Gary H. McClelland. Data analysis: A model - comparision approach, (Harcourt Brace Jovanovich, 1989). 
TABLE 1. RESULTS OF THE MEASURING MODEL ANALYSIS

\begin{tabular}{|c|c|c|c|c|c|c|c|c|}
\hline Construct & Item & Factor & $M$ & $\overline{\text { SD }}$ & t- & Cronbach alpha & $\overline{C R}$ & $\overline{\mathrm{AVE}}$ \\
\hline \multirow{4}{*}{ Distributive justice } & DJUST1 & $0.823^{*}$ & 0.822 & 0.041 & 19.838 & \multirow{4}{*}{0.901} & \multirow{4}{*}{0.93} & \multirow{4}{*}{0.77} \\
\hline & DJUST2 & $0.912^{*}$ & 0.912 & 0.017 & 55.081 & & & \\
\hline & DJUST3 & $0.852^{*}$ & 0.854 & 0.035 & 24.503 & & & \\
\hline & DJUST4 & $0.927^{*}$ & 0.926 & 0.015 & 60.512 & & & \\
\hline \multirow{3}{*}{ Procedural justice } & PJUST1 & $0.850^{*}$ & 0.852 & 0.041 & 20.808 & \multirow{3}{*}{0.854} & \multirow{3}{*}{0.91} & \multirow{3}{*}{0.77} \\
\hline & PJUST3 & $0.890^{*}$ & 0.890 & 0.032 & 28.151 & & & \\
\hline & PJUST4 & $0.899^{*}$ & 0.899 & 0.021 & 42.445 & & & \\
\hline \multirow{4}{*}{ Interaction justice } & IJUST1 & $0.837^{*}$ & 0.838 & 0.040 & 21.040 & \multirow{4}{*}{0.908} & \multirow{4}{*}{0.94} & \multirow{4}{*}{0.79} \\
\hline & IJUST2 & $0.921^{*}$ & 0.922 & 0.018 & 52.018 & & & \\
\hline & IJUST3 & $0.929^{*}$ & 0.930 & 0.020 & 47.012 & & & \\
\hline & IJUST4 & $0.854^{*}$ & 0.854 & 0.037 & 22.884 & & & \\
\hline \multirow{2}{*}{$\begin{array}{l}\text { Satisfaction with } \\
\text { service recovery }\end{array}$} & RSAT1 & $0.941^{*}$ & 0.940 & 0.019 & 49.549 & \multirow{2}{*}{0.878} & \multirow{2}{*}{0.94} & \multirow{2}{*}{0.89} \\
\hline & RSAT3 & $0.947^{*}$ & 0.947 & 0.014 & 69.018 & & & \\
\hline \multirow{2}{*}{ Overall satisfaction } & OSAT1 & $0.945^{*}$ & 0.944 & 0.014 & 65.384 & \multirow{2}{*}{0.871} & \multirow{2}{*}{0.94} & \multirow{2}{*}{0.89} \\
\hline & OSAT3 & $0.937^{*}$ & 0.936 & 0.017 & 53.782 & & & \\
\hline \multirow{3}{*}{$\begin{array}{r}\text { Communication by } \\
\text { word of mouth }\end{array}$} & COM1 & $0.904^{*}$ & 0.903 & 0.028 & 32.358 & \multirow{3}{*}{0.933} & \multirow{3}{*}{0.96} & \multirow{3}{*}{0.88} \\
\hline & $\mathrm{COM} 2$ & $0.969^{*}$ & 0.969 & 0.007 & 135.192 & & & \\
\hline & $\mathrm{COM} 3$ & $0.944^{*}$ & 0.944 & 0.014 & 67.628 & & & \\
\hline \multirow{4}{*}{$\begin{array}{r}\text { Service re-use } \\
\text { intentions }\end{array}$} & INT1 & $0.931^{*}$ & 0.930 & 0.016 & 56.656 & \multirow{3}{*}{0.833} & \multirow{3}{*}{0.90} & \multirow{3}{*}{0.75} \\
\hline & INT2 & $0.914^{*}$ & 0.914 & 0.023 & 39.065 & & & \\
\hline & INT3 & $0.738^{*}$ & 0.737 & 0.081 & 9.052 & & & \\
\hline & IM1 & $0.899 *$ & 0.899 & 0.021 & 42.608 & \multirow{3}{*}{0.812} & \multirow{3}{*}{0.89} & \\
\hline \multirow[t]{2}{*}{ Image } & IM2 & $0.887^{*}$ & 0.887 & 0.030 & 29.156 & & & 0.73 \\
\hline & IM3 & $0.763^{*}$ & 0.760 & 0.077 & 9.851 & & & \\
\hline & OBS1 & $0.785^{*}$ & 0.778 & 0.095 & 8.292 & & & \\
\hline Switching obstacles & OBS2 & $0.928^{*}$ & 0.925 & 0.041 & 22.438 & 0.860 & 0.82 & 0.78 \\
\hline & OBS3 & $0.935^{*}$ & 0.928 & 0.033 & 27.703 & & & \\
\hline
\end{tabular}

Source: Calculated by the Authors

According to the results in Table 1, it can be concluded that the scales used in this research are one-dimensional, reliable and show the satisfactory level of convergent validity. All the factor loadingsof the variables of indicators on the corresponding factorexceed 0.7 and they are statistically significant $(p<0.05)$, Cronbach alpha coefficients for all the scales exceed0.8. Also, 
Composite Reliability indicator and AVE indicators for all the scales exceed 0.7, i.e.0.5 (as recommended by Hair et. al. (2010)). C.R. indicators for the analyzed scales range from 0.82 to 0.96 , while AVE indicators range from 0.73 to 0.89 .

Discrimination validity was checked on the basis of comparison between AVE indicatorsand squaredcorrelation coefficientsbetween certain constructs (Fornell, Larcker, 1981). The results of the checked discrimination validity are presented in Table 2.

TABLE 2. INTER-CORRELATION MATRIX OF THE CONSTRUCTS AND AVE INDICATORS

\begin{tabular}{llllllllll}
\hline \hline Construct & DJUST & PJUST & IJUST & RSAT & OSAT & COM & INT & IM & OBS \\
\hline \hline DJUST & $\mathbf{0 . 7 7}$ & & & & & & & & \\
PJUST & 0.39 & $\mathbf{0 . 7 7}$ & & & & & & & \\
IJUST & 0.34 & 0.51 & $\mathbf{0 . 7 9}$ & & & & & & \\
RSAT & 0.62 & 0.57 & 0.51 & $\mathbf{0 . 8 9}$ & & & & & \\
OSAT & 0.28 & 0.35 & 0.40 & 0.40 & $\mathbf{0 . 8 9}$ & & & & \\
COM & 0.20 & 0.24 & 0.30 & 0.32 & 0.42 & $\mathbf{0 . 8 8}$ & & & \\
INT & 0.16 & 0.19 & 0.19 & 0.19 & 0.51 & 0.40 & $\mathbf{0 . 7 5}$ & & \\
IM & 0.23 & 0.29 & 0.35 & 0.34 & 0.48 & 0.48 & 0.43 & $\mathbf{0 . 7 3}$ & \\
OBS & 0.05 & 0.09 & 0.04 & 0.02 & 0.11 & 0.07 & 0.06 & 0.08 & $\mathbf{0 . 7 8}$ \\
\hline \hline
\end{tabular}

Source: Calculated by the Authors

It is possible, according to Table 2, that all AVE indicators (diagonally presented) exceed squared correlation coefficients, so it can be concluded that there is an appropriate degree of discrimination validity regarding the measurement scales.

\section{STRUCTURAL MODEL}

The research hypotheses were tested through analyzing the structural model of correlation between particular constructs.In order to find out the statistical significance of certain relations, the bootstraping re-sampling technique on 500 sub-samples was used. The results of the structural model analysis are shown in Table 3.

According to the results based on the structural model analysis, the accepted hypotheses include $\mathrm{H} 1, \mathrm{H} 2, \mathrm{H} 3, \mathrm{H} 5, \mathrm{H} 6, \mathrm{H} 7, \mathrm{H} 8, \mathrm{H} 9$ and $\mathrm{H} 10$. Therefore, distributive justice $(\beta=0.452)$, procedural justice $(\beta=0,293)$ and interaction justice $(\beta=0.184)$ have a statistically significant $(p<0.05)$ positive effect on the service recovery satisfaction. Further, the service recovery satisfaction has a statistically positive effect on spreading positive communication by word of mouth $(\beta=0.253)$ and overall satisfaction with the service $(\beta=0.631)$. Also, the overall satisfaction positively affects behavioral intentions $(\beta=0.717)$ and communication by word of mouth $(\beta=0.446)$, which has a positive effect on the customer's intention to use the service again $(\beta=0.631)$. Finally, distributive justice positively affects (positive effect), through service recovery satisfaction, behavioral intentions $(\beta=0.242)$ and positive communication by word of mouth $(\beta=0.196)$. The role of service recovery satisfaction was, thus, confirmed as a variable of mediator. 
TABLE 3. ANALYSIS OF THE STRUCTURAL MODEL

\begin{tabular}{|c|c|c|c|c|c|c|c|}
\hline & Hypotheses & $\begin{array}{l}\text { Original sample } \\
\text { standardized } \\
\text { coefficient }(\beta)\end{array}$ & $\begin{array}{l}\text { Means } \\
(M)\end{array}$ & $\begin{array}{l}\text { Standard } \\
\text { error } \\
\text { (STERR) }\end{array}$ & $\begin{array}{l}\mathrm{t}-\text { values }(\mid \beta \\
\text { /STERR } \mid)\end{array}$ & $\mathrm{R}^{2}$ & $\begin{array}{l}\text { Accepted } \\
\text { hypotheses }\end{array}$ \\
\hline $\mathrm{H} 1$ & 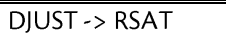 & 0.452 & 0.441 & 0.083 & $5.45^{*}$ & & accepted \\
\hline $\mathrm{H} 2$ & PJUST $>>$ RSAT & 0.293 & 0.285 & 0.091 & $3.21^{*}$ & 0.77 & accepted \\
\hline $\mathrm{H} 3$ & IJUST-> RSAT & 0.184 & 0.188 & 0.083 & $2.22^{*}$ & & accepted \\
\hline $\mathrm{H} 4$ & RSAT $->$ INT & -0.018 & -0.006 & 0.096 & 0.187 & 0.57 & not-accepted \\
\hline $\mathrm{H} 5$ & $\begin{array}{ll}\text { RSAT } & \rightarrow \\
\text { COMMUNIC } & \end{array}$ & 0.253 & 0.250 & 0.096 & 2.65 & 0.49 & accepted \\
\hline $\mathrm{H} 6$ & $\begin{array}{l}\text { COMMUNIC- } \\
>\text { INTENTION }\end{array}$ & 0.631 & 0.634 & 0.072 & $8.75^{*}$ & & accepted \\
\hline $\mathrm{H} 7$ & RSAT->OSAT & 0.631 & 0.634 & 0.072 & $8.75^{*}$ & 0.39 & accepted \\
\hline $\mathrm{H} 8$ & $\begin{array}{l}\text { OSAT } \\
\text { INTENTION }\end{array}$ & 0.717 & 0.707 & 0.082 & $8.77^{*}$ & & accepted \\
\hline $\mathrm{H} 9$ & $\begin{array}{ll}\text { OSAT } & \rightarrow \\
\text { COMMUNIC } & \end{array}$ & 0.446 & 0.444 & 0.099 & $4.47^{*}$ & & accepted \\
\hline $\mathrm{H} 10$ & $\begin{array}{l}\text { DJUST->RSAT- } \\
>\text { INTENTION }\end{array}$ & 0.242 & 0.234 & 0.056 & $4.31^{*}$ & & accepted \\
\hline \multirow[t]{2}{*}{$\mathrm{H} 10$} & $\begin{array}{l}\text { DJUST->RSAT- } \\
>\text { COMMUNIC }\end{array}$ & 0.196 & 0.194 & 0.054 & $3.66^{*}$ & & accepted \\
\hline & IMIG $->$ RSAT & 0.120 & 0.127 & 0.078 & 1.53 & & \\
\hline $\mathrm{H} 11$ & $\begin{array}{l}\text { IMIG*DJUST- } \\
>\text { OSAT }\end{array}$ & 0.037 & 0.020 & 0.118 & 0.32 & & not-accepted \\
\hline $\mathrm{H} 12$ & $\begin{array}{l}\text { IMIG*PJUST- } \\
\text { > RSAT }\end{array}$ & -0.079 & -0.048 & 0.128 & 0.62 & & not-accepted \\
\hline \multirow[t]{3}{*}{$\mathrm{H} 13$} & IMIG*IJUST->RSAT & 0.103 & 0.081 & 0.114 & 0.91 & & not-accepted \\
\hline & $\begin{array}{l}\text { OBST- } \\
>\text { INTENTION }\end{array}$ & -0.004 & -0.001 & 0.077 & 0.08 & & \\
\hline & $\begin{array}{l}\text { OBST- } \\
>\text { COMMUNIC }\end{array}$ & 0.070 & 0.075 & 0.087 & 0.82 & & \\
\hline $\mathrm{H} 14$ & $\begin{array}{l}\text { OBST*RSAT- } \\
>\text { INTENTION }\end{array}$ & 0.064 & 0.069 & 0.118 & 0.54 & & not-accepted \\
\hline $\mathrm{H} 15$ & $\begin{array}{l}\text { OBST*RSAT- } \\
>\text { COMMUNIC }\end{array}$ & 0.170 & 0.170 & 0.086 & 1.97 & & not-accepted \\
\hline
\end{tabular}

Source: Calculated by the Authors, ${ }^{*} \mathrm{p}<0.05$

The following hypotheses were not accepted: $\mathrm{H} 4, \mathrm{H} 11, \mathrm{H} 12, \mathrm{H} 13, \mathrm{H} 14$ and $\mathrm{H} 15$. Service recovery satisfaction did not have a statistically significant effect on the behavioral intentions of customers. However, it is possible to see from the research results that the service recovery satisfaction affects customers' intention to return as a customer through their overall satisfaction. 
In addition, no statistically significant moderator's influence of the image or switching barriers on certain constructs was not confirmed according to the researched model.

Using the model, $77 \%$ of variances regarding the construct of service recovery satisfaction was explained; also, $57 \%$ of variance of construct related to the customer's use intention, $49 \%$ of the construct of positive communication by word of mouth and 39\% of variance of the overall satisfaction construct. The model satisfactorily explains certain constructs (average-very good).

\section{DISCUSSION}

As it was assumed in the context of justice theory, distributive, procedural and interaction justice affect service recovery satisfaction. The largest importance refers to distributive justice, i.e. customers are most interested in the final outcome of service recovery. It is followed by procedural justice and then by interaction justice.This corresponds with the meta-analysis by Orsingher, Valentini and deAngelis ${ }^{64}$ in terms of distributive justice, but not the two others, where the order is reverse. Service recovery satisfaction has a significantly positive effect on the overall satisfaction, so it is needed to take into account the quality of every service recovery. Service recovery satisfaction directly affects communication by word of mouth, which is also affected by the overall satisfaction. Communication by word of mouth is an extremely important consequence of service recovery satisfaction because customers often refer to the experiences of other customers and, thus, acquire the perception of the company. Finally, the aim of each company is to have the customer who repeatedly uses the service and becomes a loyal user, which is strongly affected by the overall satisfaction and communication by word of mouth. The above-mentioned finding is also in accordance with the research conducted by Orsingher, Valentivi and de Angelis ${ }^{65}$ but, in their research, there is no statistically significant effect of the overall satisfaction on communication by word of mouth.

The moderator's effect of the image and switching barriers were not confirmed in this research, which can be explained by orientating customers to direct service benefits (e.g. lower cost) without taking especially into account the image of particular operators or probably by lower perceived customer exit barriers because a smaller number of subjects had a contract with the main mobile operator.

\section{MANAGERIAL IMPLICATIONS}

As any aspect of justice have an effect on service recovery satisfaction, the paper points out the importance of appropriate behavior of service staff in terms of following procedures, adequate interactions and results which the customer expects. Yet, distributive justice is of the largest importance, which leads to the conclusion that customers mostly take care of the final service outcome. It is followed by procedural justice, which indicates the need to provide a fast response to the complaint as well as the existence of good service recovery procedures. Based on this research, interactive justice is of the least importance but still we should not neglect nice and emphatic behavior at dealing with delicate service failure recovery.

Recovery service satisfaction is crucial for the overall satisfaction and retention of service users. The importance of positive communication by word of mouth is emphasized since it also affects

${ }^{64}$ Chiara Orsingher, Sara Valentini, and Matteo deAngelis, „A meta-analysis of satisfaction with complaint handling in services". Journal of the Academy of Marketing Science, 38, no. 2 (2010) 169-186.

${ }^{65}$ Ibid. 
the customer's intention to return as a customer. Companies should, therefore, take into consideration the relationships between these elements.

Since there is no modeling effect of the image on service recovery satisfaction, companies should reconsider such element, while the unstated importance of switching costs indicates the necessity of providing the high quality service to every customer because $s /$ he may be inclined to change the service provider.

\section{LIMITATIONS}

The research limitations mostly refer to the analyzed problem and sample. The research was conducted in the context of mobile communication services, providing specific results for this service in Croatia. However, it does not enable the generalization of results. Including other services in the research, different in terms of the process features and customer's involvement, would expand the insights into the studied effects. Also, it would lead to discovering the services at which the image significantly contributes to the customer's service recovery satisfaction as well as barriers for switching in case of the services for which such barriers are relevant. The research was conducted in the Croatian context. It would be interesting to carry out research in other countries where, depending on the situation of competition related to mobile communication services, more or less comparable results could be obtained.

The sample used in the research is small and limited on the population of students, who are relatively powerful consumers of telecommunication services but represent just one market segment. A larger sample including different groups of subjects in terms of their demographic characteristics would provide more reliable results and enable some wider generalization of the research results.

\section{REFFERENCE}

Aiken Leona S. and Stephen G. West. Multiple regression: Testing and interpreting interactions, Newbury Park:Sage Publications, 1991.

Andreassen, Tor W. „From Disgust to Delight: Do Customers Hold a Grudge?", Journal of Service Research, 4, no. 1 (2001): 39-49.

Andreassen, Tor W., and Bodil Linedstad. "Customer Loyalty and Complex Services", International Journal of Service Industry Management, 8, no. 4: 1-33.

Blodgett, Jeffrey G., Donna J. Hill, and Stephan S. Tax. „The Effects of Distributive, Procedural, and Interactional Justice on Post-Complaining Behavior", Journal of Retailing, 73, no. 2 (1997): 185-210.

Chin, Wynne W., Barbara L. Marcolin and Peter R. Newsted. „APartial Least Squares latent variable modelingapproach for measuring interaction effects:results from a Monte Carlo simulation studyand voice mail emotion/adoption study", inProceedings of the Seventeenth international conference on information systems edited by Janice DeGross, Sirkka Jarvenpaa, and Ananth Srinivasan, 20-41. Cleveland, Ohio, 1996.

Croatian Bureau of Statistics (2012), Studenti u ak. godini 2010./2011., http://www.dzs.hr/Hrv_Eng/publication/2012/SI-1445.pdf (retrieved on 10/09/2012)

Hair, Joseph F. and others. Multivariate Data Analysis, Upper Saddle River, New Jersey: Pearson Education, 2009. 
Hensler, Joerg and Georg Fassot. „Testing Moderating effects in PLS Path Models: An Illustration of Available Procedures", inHandbook of Partial Least Squares: Concepts, Methods and Applications edited by Esposito Vinzi and others, 713-735, New York: Springer, 2010.

Homburg, Christian, and Andreas Furst. „How Organizational Complaint Handling Drives Customer Loyalty: An Analysis of the Mechanistic and the Organic Approach", Journal of Marketing, 69, no. 3 (2005): 95-114.

Jones, Michael A., David L. Mothersbaugh, and Sharon E. Beatty. "Switching Barriers and Repurchase Intentions in Services", Journal of Retailing, 76, no. 2 (2000): 259-274.

Judd, Charles M. and Gary H. McClelland. Data analysis: A model - comparision approach, Harcourt Brace Jovanovich, 1989.

Lai, Chi-Shiun, Chin-Jen Chiu, Chin-Fang Yang, and Da-Chang Pai. „The Effect of Corporate Social Responsibility on Firm Performance: The Mediating Effect of Industrial Brand Equity and Corporate Reputation“, Journal of Business Ethics, 95, no. 3 (2010): 457-469.

Lai, Fujun, Mitch Griffin, and Barry J. Babin. „How quality, value, image, and satisfaction create loyalty at a Chinese telecom“, Journal of Business Research, 62, no. 10 (2009): 980-986.

Liao, Hui. „Do It Right This Time: The Role of Employee Service Recovery Performance in Customer-Perceived Justice and Customer Loyalty After Service Failures", Journal of Applied Psychology, 92, no. 2 (2007): 475-489.

Lovelock, Christopher, and Jochen Wirtz. Services Marketing: People, Technology, Strategy, Pearson Prentice Hall, 2007.

Maxham, James G., and Richard G. Netemeyer. „Modeling customer perceptions of complaint handling over time: the effects of perceived justice on satisfaction and intent", Journal of Retailing, 78, no. 4 (2002): 239-252.

Maxham, James G., and Richard G. Netemeyer, "Firm Reap What They Sow: The Effects of Shared Values and Perceived Organizational Justice on Customers' Evaluations on Complain Handling", Journal of Marketing, 67, no. 1 (2003): 46-62.

McCollough, Michael A., Leonard L. Berry, and Manjit S. Yadav. „An Empirical Investigation of Customer Satisfaction after Service Failure and Recovery", Journal of Service Research, 3, No. 2 (2000): 121-137.

Motta, Massimo. Competiton Policy: Theory and Practice, Cambridge University Press, 2004.

Nikbin, Davoud, Ishak Ismail, Malliga Marimuthu, and Mohammad Jalalkamali. „Perceived Justice in Service Recovery and Recovery Satisfaction: The Moderating Role of Corporate Image“, International Journal of Marketing Studies, 2, no. 2 (2010) 47-56.

Oliver, Richard L. Satisfaction: A Behavioral Perspective on the Consumer, The mcGraw-Hill Companies, Inc., 1997.

Orsingher, Chiara, Sara Valentini, and Matteo deAngelis. „A meta-analysis of satisfaction with complaint handling in services". Journal of the Academy of Marketing Science, 38, no. 2 (2010) 169-186.

Patterson, Paul G., Elizabeth Cowley, and Kriengsin Prasongsukarn. „Service failure recovery: The moderating impact of individual-level cultural value orientation on perceptions of justice", International Journal of Research in Marketing, 23, no. 3 (2006) 263-277.

Porter, Michael. Competitive Strategy: Techniques for analiysing industries and competitors, New York: The Free Press, 1980.

Reichheld, Frederik F., and Earl W. Sasser Jr.,Zero Defections: Quality Comes to Services“, Harvard Business Review, 68, no. 5 (1990): 105-111.

Sabharwal, Nidhi, Harmeen Soch, and Harsandaldeep Kaur. „Are we satisfied with incompetent services? A scale development approach for service recovery", lournal of Services Research, 10, no. 1 (2010): 125-142. 
Schoefer, Klaus. "The role of cognition and affect in the formation of customer satisfaction judgements concerning service recovery encounters", Journal of Consumer Behaviour, 7, no. 3 (2008): 210-221.

Smith, Amy K., Ruth N. Bolton, and Janet Wagner. „A Model of Customer Satisfaction with Service Encounters Involving Failure and Recovery", Journal of Marketing Research, 36, no. 3 (1999): 356-372.

Sparks, Beverly A., andLiz Fredline. „Providing an Explanation for Service Failure: Context, Content, and Customer Responses, Journal of Hospitality \& Tourism Research, 31, no. 2 (2007): 241-260.

Sparks, Beverly A., and Janet R. McColl-Kennedy. "Justice strategy options for increased customer satisfaction in a services recovery setting", Journal of Business Research, 54, no. 3 (2001): 209-218.

Tax, Stephen S., Stephen W. Brown, and Murali Chandrashekaran. „Customer Evaluations of Service Complaint Experiences: Implications for Relationship Marketing", Journal of Marketing, 62, no. 2 (1998): 60-76.

Urbonavičius, Sigitas, and Robertas Ivanauskas. "Evaluation of Multiple Retailers' Market Positons on the Basis on Image Attributes Measurement", Journal of Business Economics and Management, 6, no.4, (2005): 199-206.

Varela-Neira, Concepcion, Rodolfo Vazquez-Casielles, and Victor Iglesias. „The effects of customer age and recovery strategies in a service failure setting", Journal of Financial Services Marketing, 15, no. 1(2010): 32-48.

Wang, Yi-Shun, Shung-Cheng Wu, Hsin-Hui Lin, andYu-Yin Wang. „The relationship of service failure severity, service recovery justice and perceived switching costs with customer loyalty in the context of e-tailing", International Journal of Information Management, 31, no. 4 (2011): 350-359.

Weun, Seungong, Sharon E. Beatty, and Michael A. Jones. "The impact of service failure severity on service recovery evaluations and post-recovery relationships", Journal of Services Marketing, 18, no. 2 (2004): 133-146.

Zeithaml, Valerie A., Mary J. Bitner, and Dwayne D. Gremler, D.D. Services Marketing, New York: McGraw-Hill, Irwin, 2006.

\section{APPENDIX: Questionnarie}

Distributive Justice

1. The outcome I received was fair

2. In resolving the problem, firm gave me what I needed

3. Given the circumstances, I feel that the firm offered adequate compensation

4. I got what I deserved from the complaint

Procedural Justice

1. The responded quickly to my complaint

2. It was hard to figure who to complain to in this (firm)

3. The (firm) showed adequate flexibility in dealing with my problem

4. With respect to its policies and procedures, (firm) handled the problem in a fair manner 
Interactional Justice

1. In dealing with my problem, (firm) personnel treated me in a courteous manner.

2. The employees seemed to care about me

3. They seemed very concerned about my problem

4. The employees' communications with me were appropriate

5. They did not appear to be telling me the truth

\section{Satisfaction with Recovery}

1. In my opinion, (firm) provided a satisfactory resolution to my problem on this particular occasion

2. I am not satisfied with (firm) handling of this particular problem

3. Regarding this particular event (most recent problem) I am satisfied with (firm)

\section{Overall Firm Satisfaction}

1. I am satisfied with my overall experience with (firm)

2. As a whole, I am not satisfied with (firm)

3. How satisfied are you overall with the quality of (firm)?

Purchase Intent

1. In the future, I intend to use banking services from my (firm)

2. If you were in the market for additional (firm) services, how likely would you be to use those services from (firm)?

3. In the near future, I will not use (firm) as my provider

Word of Mouth

1. How likely are you to speread positive word of mouth about (firm)?

2. I would recommend (firm) to my friends

3. If my friends were looking to use mobile communication service, I would tell them to try (firm).

Image

1. My overall perpeptions of total experience in (firm) is rather good

2. My comparative perceptions of (firm) with other competitors are very good

3. I believe in a good long-term future of this (firm)

Perceived Switching Costs

1. It would cost me a lot of money to switch from my current (firm) to another one

2. It would take me a lot of effort to switch from my current (firm) to another one

3. It would take me a lot of time to switch from my current (firm) to another one

4. I would feel uncertain of I had to choose a new (firm). 